\title{
Wetting of Sn-Zn-Ga and Sn-Zn-Na Alloys on Al and Ni Substrate
}

\author{
TOMASZ GANCARZ ${ }^{10},{ }^{1,4}$ PIOTR BOBROWSKI, ${ }^{1}$ SYLWIA PAWLAK, ${ }^{2}$ \\ NORBERT SCHELL, ${ }^{3}$ ROBERT CHULIST, ${ }^{1}$ and KATARZYNA JANIK ${ }^{1}$
}

1.-Institute of Metallurgy and Materials Science, Polish Academy of Sciences, Reymonta 25 St., 30-059 Kraków, Poland. 2.-Wroclaw Research Centre EIT+, Stablowicka 147 St., 54-066 Wrocław, Poland. 3.-Institute of Materials Research, Helmholtz-Zentrum Geesthacht, MaxPlanck-Strasse 1, 21502 Geesthacht, Germany. 4.—e-mail: t.gancarz@imim.pl

\begin{abstract}
Wetting of $\mathrm{Al}$ and $\mathrm{Ni}$ substrate by $\mathrm{Sn}-\mathrm{Zn}$ eutectic-based alloys with 0.5 (wt.\%) of $\mathrm{Ga}$ and 0.2 (wt.\%) of $\mathrm{Na}$ was studied using the sessile drop method in the presence of ALU33 ${ }^{\circledR}$ flux. Spreading tests were performed for $60 \mathrm{~s}, 180 \mathrm{~s}$, and $480 \mathrm{~s}$ of contact, at temperatures of $503 \mathrm{~K}, 523 \mathrm{~K}$ and $553 \mathrm{~K}\left(230^{\circ} \mathrm{C}, 250^{\circ} \mathrm{C}\right.$, and $280^{\circ} \mathrm{C}$ ). After cleaning the flux residue from solidified samples, the spreading areas of $\mathrm{Sn}-\mathrm{Zn} 0.5 \mathrm{Ga}$ and $\mathrm{Sn}-\mathrm{Zn} 0.2 \mathrm{Na}$ on $\mathrm{Al}$ and $\mathrm{Ni}$ substrate were determined. Selected, solidified solder-pad couples were cross-sectioned and subjected to scanning electron microscopy with energy dispersive spectroscopy, x-ray diffraction study and synchrotron measurements of the interfacial microstructure and identification of the phases. The growth of the intermetallic $\mathrm{Ni}_{5} \mathrm{Zn}_{21}$ phase layer was studied at the solder/Ni substrate interface, and the kinetics of the formation and growth of the intermetallic layer were determined. The formation of interlayers was not observed on the $\mathrm{Al}$ pads. On the contrary, dissolution of the $\mathrm{Al}$ substrate and migration of $\mathrm{Al}-$ rich particles into the bulk of the solder were observed.
\end{abstract}

Key words: Wetting, Sn-Zn alloys, microstructure, kinetics, chemical reaction, $\mathrm{Al}$ and $\mathrm{Ni}$ substrate, synchrotron measurements

\section{INTRODUCTION}

Bearing in mind the EU Directive on the restriction of hazardous substances, and economical considerations, Sn-Zn alloys form the main group of solders to replace traditional materials. ${ }^{1}$ However, $\mathrm{Sn}-\mathrm{Zn}$ eutectic solder is difficult to use, especially due to its highly active characteristics. ${ }^{2}$ Therefore, alloying additives are combined with $\mathrm{Sn}-\mathrm{Zn}$ alloys. ${ }^{1,3-6}$ The microstructures of soldered joints with Sn-9Zn binary alloys were investigated, as were their interfaces with $\mathrm{Cu}^{2,6-9}$ However, coupon testing demonstrated a thickening of the $\mathrm{Cu}_{5} \mathrm{Zn}_{8}$ phase layer at the interface, as well as the formation of voids, with increasing aging time. ${ }^{10}$ Therefore, the Ni layer at the interface caused the formation of

(Received April 19, 2017; accepted September 6, 2017; published online September 15, 2017) intermetallic compounds (IMCs) from the $\mathrm{Cu}-\mathrm{Zn}$ system to be blocked, $2,11-13$ and allowed the formation of Sn-Ni-Zn phases. ${ }^{14}$ Interfacial reactions between Sn-Zn solder and $\mathrm{Ni}$ will occur during reflow and subsequent solid-state annealing, and $\mathrm{Ni}_{5} \mathrm{Zn}_{21}$ is the primary phase formed at the $\mathrm{Sn}$ 9 wt. $\% \mathrm{Zn} / \mathrm{Ni}$ interface. ${ }^{15-17}$ The authors ${ }^{13}$ observed that the $\mathrm{Ni}$ and $\mathrm{Ni}(\mathrm{P})$ coating layer caused a reduction in the thickness of the IMC layer at the interface compared to $\mathrm{Cu}$ substrate, and that the thickness of the IMC layer remained at the same level for up to 15 min during soldering. A ball shear test showed that the electroless $\mathrm{Ni}(\mathrm{P})$ and electrolytic $\mathrm{Ni}$ bond pads as reflowed joints exhibited high strength. ${ }^{13}$ The introduction of a new coating layer $\left(\mathrm{Au}^{2}\right)$ did not provide protection before the formation of the Ni-Zn phases. ${ }^{2}$ Taking into account that $\mathrm{Zn}$ has a strong chemical affinity with $\mathrm{Cu}$, the amount of soluble $\mathrm{Zn}$ content in the solder should be reduced. ${ }^{18-20}$ Similar behavior for $\mathrm{Sn}-\mathrm{Zn}$ with $\mathrm{Ga}^{21}$ 
and $\mathrm{Na}^{22}$ on $\mathrm{Cu}$ substrate was observed. The addition of 0.5 (wt.\%) Ga to eutectic Sn-Zn caused a reduction in the IMC layer at the interface. ${ }^{21}$ The addition of 0.2 (wt.\%) $\mathrm{Na}$ to $\mathrm{Sn}-\mathrm{Zn}$ caused the formation of $\mathrm{NaZn}_{13}$ and Na-Sn precipitates, which led to improved mechanical properties of the solder and a slight reduction in the IMC layer at the interface. ${ }^{22}$ In the case of soldering on Ni substrate, with Sn-Zn containing $\mathrm{Ga}$ and $\mathrm{Na}$, similar behavior is expected. However, the level of $\mathrm{Zn}$ in $\mathrm{Sn}-\mathrm{Zn}$ alloys caused the formation of ternary IMCs from Sn-Zn$\mathrm{Ni}$, as shown in Ref. 15.

An alternative for the automotive industry in soldering is aluminum, which has a broad range of applications including the ability to join $\mathrm{Al}$ with $\mathrm{Cu}$ using Sn-Zn alloys. ${ }^{23}$ In the literature, ${ }^{8,23}$ it has been observed that the spreading area on $\mathrm{Al}$ is one order of magnitude greater compared to that on $\mathrm{Cu}$ substrate. During soldering of $\mathrm{Sn}-\mathrm{Zn}$ alloys on $\mathrm{Al}$ substrate, IMC layers are not formed at the interface, and the $\mathrm{Al}$ dissolves in the solder. ${ }^{24}$ It is well known that the cooling rate significantly affects the resulting microstructure array and solder alloy properties (e.g. mechanical, corrosion and wettability), including their corresponding IMC formation when this is clearly constituted. ${ }^{25-29}$ The formation of aluminum dendrites is based on the dissolution of aluminum grains, which are dissolved from their centers by the surrounding $\mathrm{Sn}$ solder. ${ }^{24}$ On the other hand, the addition of $\mathrm{Ag}^{23,30}$ and $\mathrm{In}^{30,31}$ to Sn$\mathrm{Zn}$ alloys improves mechanical and wetting properties. The results in Ref. 24 show that the resultant increasing shear strength is correlated with the increasing volume of $\mathrm{Al}$ dissolved in the $\mathrm{Sn}-\mathrm{Zn}-\mathrm{XAg} /$ $\mathrm{Al}$ joint over longer soldering time. The alloying elements reduce the reactivity of $\mathrm{Zn}$, which could improve the wettability of the $\mathrm{Al}$ substrate.

In this work, $\mathrm{Sn}-\mathrm{Zn}+0.5 \mathrm{Ga}$, and $\mathrm{Sn}-\mathrm{Zn}+0.2 \mathrm{Na}$ (wt.\%) alloys were used to study the spreading of $\mathrm{Al}$ and Ni substrates in the presence of flux. The aim of this work is to study the effect of spreading time and temperature on the microstructure evolution of solder/Al and solder/Ni couples. The kinetics of growth of the IMC layer formed at the interface, on Ni substrate, was determined.

\section{EXPERIMENTAL}

The eutectic Sn-Zn alloy with additions $0.5 \mathrm{Ga}$ and $0.2 \mathrm{Na}$ (wt.\%), on $\mathrm{Al}(99.9 \%)$ and $\mathrm{Ni}(99.9 \%)$ substrates were studied using the sessile drop method (SD). The alloys had been characterized in previous studies.,22,32 For soldering, the as-cast solders were cut into pieces of $\sim 0.2 \mathrm{~g}$ each, and $\mathrm{Al}$ and $\mathrm{Ni}$ substrates $(25 \times 20 \times 0.25 \mathrm{~mm})$ without special treatment were used. The tests were carried out with the setup used in studies of Sn-Zn, ${ }^{8}$ which enables the quick transfer of the sample to the already heated furnace, and out of it after the designated time, so that both the heating rate and cooling rate are high. To study the effect of extended time of contact and temperature on the evolution of the solder-substrate interface, samples were held for $60 \mathrm{~s}, 180 \mathrm{~s}$, and $480 \mathrm{~s}$ of contact, at temperatures of $503 \mathrm{~K}, 523 \mathrm{~K}$, and $553 \mathrm{~K}\left(230^{\circ} \mathrm{C}, 250^{\circ} \mathrm{C}\right.$, and $280^{\circ} \mathrm{C}$, respectively). Spreading tests were performed using ALU33 ${ }^{\circledR}$ flux applied to the solder sample and the surrounding part of the substrate. The flux components are aminoethylethanolamine $\left(\mathrm{C}_{4} \mathrm{H}_{12} \mathrm{~N}_{2} \mathrm{O}\right)$ and ammonium fluoroborate $\left(\mathrm{NH}_{4} \mathrm{BF}_{4}\right)$. According to ISO 9454-1, this is the 2.1.2-type flux, i.e., organic, water-soluble and activated with halides. The role of the flux is to break and remove the oxide film from the $\mathrm{Al}$ and $\mathrm{Ni}$ surfaces. The reported spreading areas are the average of three measurements taken from independent solidified samples after washing away flux residue with tap water and acetone. Measurements of spreading area were conducted in photo obtained 3 droplets using Getarea in CorelDraw, as described in Ref. 8. After wetting tests, selected solidified solder/substrate couples were cut perpendicular to the plane of the interface, mounted in conductive resin and polished for microstructural characterization. Microstructural and energy dispersive spectroscopy (EDS) analyses were performed via scanning electron microscopy (SEM) using a Quanta 3D FEG system, at $20 \mathrm{kV}$, with the standardless analysis EDAX system based on Genesis 4000 software. Phase identification was carried out using x-ray diffraction (XRD). In order to obtain information from the bulk, diffraction of high-energy synchrotron radiation $(87.1 \mathrm{keV}, \lambda=0.142342 \mathrm{~nm})$ using beam line P07 at DESY (Hamburg, Germany) was used. Transmission geometry and the high penetration depth of synchrotron radiation allow diffraction data to be obtained from representative large sample volumes. The diffraction data were collected using an area detector, located at a distance of $1070 \mathrm{~mm}$ from the sample, with a beam size of $0.5 \times 0.5 \mathrm{~mm}^{2}$. To ensure that the optimal volume of $\mathrm{Sn}-\mathrm{Zn} 0.2 \mathrm{Na} / \mathrm{Ni}$ is in the beam, the sample was measured at three different sites across the interface. The most representative area was chosen for phase analysis. Additionally, to bring all grains into diffraction (all planes fulfil the Bragg condition), the sample was continuously rotated around the $\omega$ axis by $-90^{\circ}<\omega<90^{\circ}{ }^{33}$ In such a way, all orientations of a $0.5 \times 0.5 \times 2 \mathrm{~mm}^{3}$ sample volume were recorded in one single image. The thicknesses of the IMC layers on the $\mathrm{Ni}$ substrate were determined in the same place, and the average value was calculated from the schedule of 12 measurements for all microstructures. ${ }^{22}$ The greatest differences were less than 3\%. To determine the diffusion coefficient described in Refs. 21 and 22 , the thickness of the IMC layer (D) is dependent on the growth rate $(k)$, the growth time $(t)$ and an exponential factor $(n)$. The character and rate of growth correlate to parameter " $n$ " as a coefficient of growth, where $n \ll 0.5$ is grain boundary diffusion, $n=0.5$ is volume diffusion and $n=1$ is chemical reaction. 
The parameters of $n$ and $k$ were determined using Grapher software by fitting to experimental data. The growth rate for interface migration was calculated using an Arrhenius-type equation.

\section{RESULTS AND DISCUSSION}

\section{The Spreading Test on Al Substrate}

Figure 1 shows the spreading area of $\mathrm{Sn}-\mathrm{Zn} 0.5 \mathrm{Ga}$ and $\mathrm{Sn}-\mathrm{Zn} 0.2 \mathrm{Na}$ on $\mathrm{Al}$ substrate. For eutectic $\mathrm{Sn}-\mathrm{Zn}$ with $\mathrm{Ga}$ content, a reduction in the spreading area over time, for each temperature, was observed. Furthermore, the spreading area was reduced as the temperature rose. For Na content, such a trend was not observed. At a lower temperature of $503 \mathrm{~K}$ $\left(230^{\circ} \mathrm{C}\right)$, the area was reduced, but at $523 \mathrm{~K}$ and $553 \mathrm{~K}\left(250^{\circ} \mathrm{C}\right.$ and $280^{\circ} \mathrm{C}$, respectively), it increased slightly. The Al substrate was dissolved in liquid solder. The surface tension of the alloys was around $540\left(\mathrm{mN} \mathrm{m}^{-1}\right), 32$ and that of the $\mathrm{Al}$ was around 900 $\left(\mathrm{mN} \mathrm{m}^{-1}\right),{ }^{34,35}$ which caused increasing surface tension of the liquid alloy and, in consequence, a reduction in the spreading area as time increased and as temperature rose. However, a different character was observed for the $\mathrm{Sn}-\mathrm{Zn}$ with 0.2 (wt.\%) $\mathrm{Na}$. It is likely that $\mathrm{Na}$, which has low surface tension (around $190^{35}$ ) and high surface activity at temperatures of $523 \mathrm{~K}$ and $553 \mathrm{~K}\left(250^{\circ} \mathrm{C}\right.$ and $280^{\circ} \mathrm{C}$ ), caused the IMC to dissolve in the liquid solder, as observed in the calorimetry study for the $\mathrm{Sn}-\mathrm{Zn} 0.2 \mathrm{Na}$ alloy. The first peak showed $(\max )$ at $517 \mathrm{~K}\left(244^{\circ} \mathrm{C}\right)$ during cooling (Fig. 1b), which was not observed during heating because the small amount of IMC dissolved over time and the effect was blurred on the curve. However, this thermal effect (peak) only occurred during heating for higher $\mathrm{Na}$ content, ${ }^{22}$ as a result of the formation of more IMCs. The $0.5 \mathrm{Ga}$ and $0.2 \mathrm{Na}$ additions to eutectic $\mathrm{Sn}-\mathrm{Zn}$ were selected because they yielded the highest value of spreading area on $\mathrm{Cu}$ substrate. ${ }^{21,22} \mathrm{~A}$ comparison of the spreading area for these alloys on $\mathrm{Al}$ to $\mathrm{Cu}$ substrates showed a similar relation for $\mathrm{Ga}$ additions, although IMC layers formed on the $\mathrm{Cu}$ substrate. For the Na content, the spreading area on the $\mathrm{Al}$ substrate increased with increasing temperature the same as on the $\mathrm{Cu}$ substrate, with one exception. At $503 \mathrm{~K}\left(230^{\circ} \mathrm{C}\right)$, the spreading area on Al reduced with time, which could be correlated with undissolved IMC precipitates and $\mathrm{Na}$ movement to the surface area being blocked. Similar results were obtained for the spreading area for eutectic Sn-Zn on Al substrate, ${ }^{8,30}$ compared with $\mathrm{Sn}-\mathrm{Zn}$ alloy with $\mathrm{Ga}$ and $\mathrm{Na}$ additions. Furthermore, with increased temperature [from $523 \mathrm{~K}$ to $\left.773 \mathrm{~K}\left(250^{\circ} \mathrm{C} \text { to } 500^{\circ} \mathrm{C} \text {, respectively }\right)^{8}\right]$ and time (from $5 \mathrm{~min}$ to $60 \mathrm{~min}^{30}$ ), the spreading area reduced. The same behavior was observed for Sn$\mathrm{Zn}$ with $\mathrm{Ag}$ and In alloys. ${ }^{30}$

During the soldering process on $\mathrm{Al}$ substrate, the microstructure of a cross section at time and temperature dependency (Figs. 2 and 3) was observed. The obtained microstructure was similar for two alloys. Therefore, time dependence was presented for Sn-Zn0.5Ga, and temperature dependence for Sn-Zn0.2Na. Figure 2 shows $\mathrm{Sn}-\mathrm{Zn} 0.5 \mathrm{Ga}$ on $\mathrm{Al}$ substrate at a temperature of $503 \mathrm{~K}\left(230^{\circ} \mathrm{C}\right)$ and for times of $1 \mathrm{~min}, 3 \mathrm{~min}$, and $8 \mathrm{~min}$. The $\mathrm{Al}$ substrate was dissolved during the soldering process and, with increasing time, the liquid solder propagated along the grain boundaries, with bigger pieces of $\mathrm{Al}$ detaching and dissolving in the solder. The highest level of dissolved $\mathrm{Al}$ was observed for $8 \mathrm{~min}$ (Fig. 2c), which is correlated with the reducing spreading area as the level of $\mathrm{Al}$ in the liquid solder increases. EDS analysis of the cross section was performed, and the results are presented in Table I. The EDS analysis shows Al dissolving in the solder (points: 4, 11, 18), but also the $\mathrm{Al}$ substrate being dissolved by solder through the grain boundary, which increased with time and was observed in microstructure and EDS analysis (points: 6, 13, 19). According to the phase diagram of Al-Sn-Zn, 36 IMCs were not detected in this system. Similar to the previous work for eutectic $\mathrm{Sn}-\mathrm{Zn}$ and $\mathrm{Sn}-\mathrm{Zn}$ with $\mathrm{Ag}$ and In additions,${ }^{30}$ the $\mathrm{Al}$ substrate was dissolved by liquid solder, which is in line with the results of this work.

Figure 3 shows the microstructure of a cross section of liquid solder $\mathrm{Sn}-\mathrm{Zn} 0.2 \mathrm{Na}$ on $\mathrm{Al}$ substrate, for a time of $8 \mathrm{~min}$ at temperatures of $503 \mathrm{~K}, 523 \mathrm{~K}$, and $553 \mathrm{~K}\left(230^{\circ} \mathrm{C}, 250^{\circ} \mathrm{C}\right.$, and $280^{\circ} \mathrm{C}$, respectively). EDS analysis was performed for temperature dependences (see Table II). Taking into account that the analysis of $\mathrm{Zn}$ and $\mathrm{Na}$ by means of SEM-EDS was difficult, because the $\mathrm{Zn}$ line $\mathrm{L}_{\alpha}$ and $\mathrm{Na}$ line $\mathrm{K}_{\alpha}$ appear close to each other, EDS analysis of $\mathrm{Na}$ was not reported in the table. It was observed that with increasing time and temperature, the liquid solder propagated along the grain boundaries. However, with increasing temperature, the area of dissolving $\mathrm{Al}$ at the interface grew faster compared to the Sn-Zn0.5Ga alloy. Taking into account the EDS analysis (points: 22, 28, 32, 33), the area of dissolving $\mathrm{Al}$ substrate by $\mathrm{Sn}-\mathrm{Zn} 0.2 \mathrm{Na}$ solder was higher compared to the Sn-Zn0.5Ga alloy. The same character of dissolving $\mathrm{Al}$ substrate by solder was observed for alloys $\mathrm{Sn}-\mathrm{Zn} 0.5 \mathrm{Ga}$ and $\mathrm{Sn}-\mathrm{Zn} 0.2 \mathrm{Na}$ through grain boundary EDS analysis (points: 24, 29,35 ), which is in line with the previous study and literature. ${ }^{23,30}$ In addition, big needles of $\mathrm{Zn}$ were observed on the microstructure (confirmed by EDS analysis points: 21, 27, 31), and these were not noted for the Sn-Zn0.5Ga alloy. Similar microstructures of $\mathrm{Sn}-\mathrm{Zn}$ solder on Al substrate were obtained by Huang et al., ${ }^{23}$ who observed partly dissolved $\mathrm{Al}$ and $\mathrm{Zn}$ needles near the interface. However, $\mathrm{Zn}$ needles were not observed in the microstructure for $\mathrm{Ag}$ additions to eutectic $\mathrm{Sn}-\mathrm{Zn},{ }^{23}$ because the $\mathrm{Zn}$ formed with Ag the IMC $\mathrm{AgZn}_{3}$, and the microstructure is close to that obtained for the Sn-Zn0.5Ga alloy. The cooling 


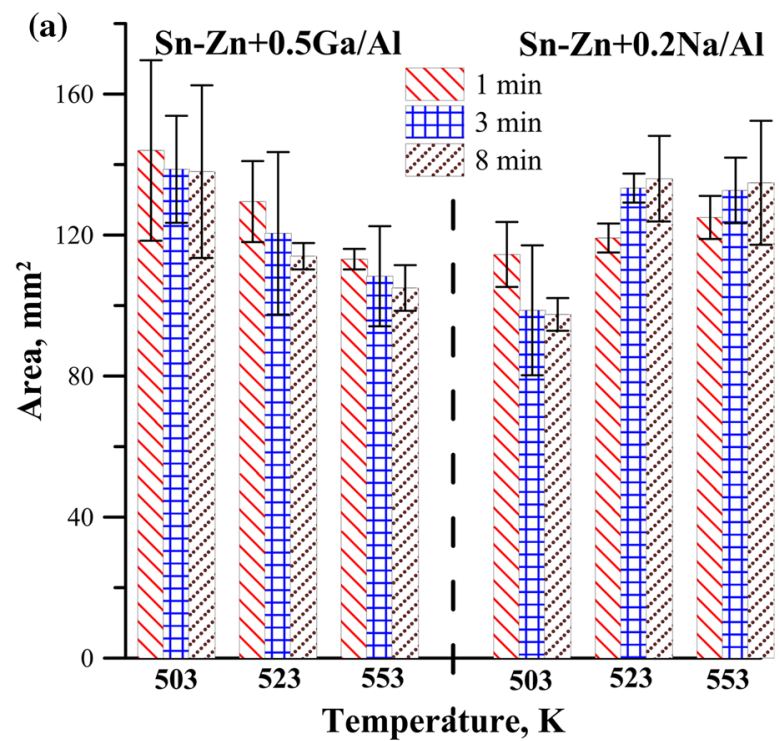

(b)

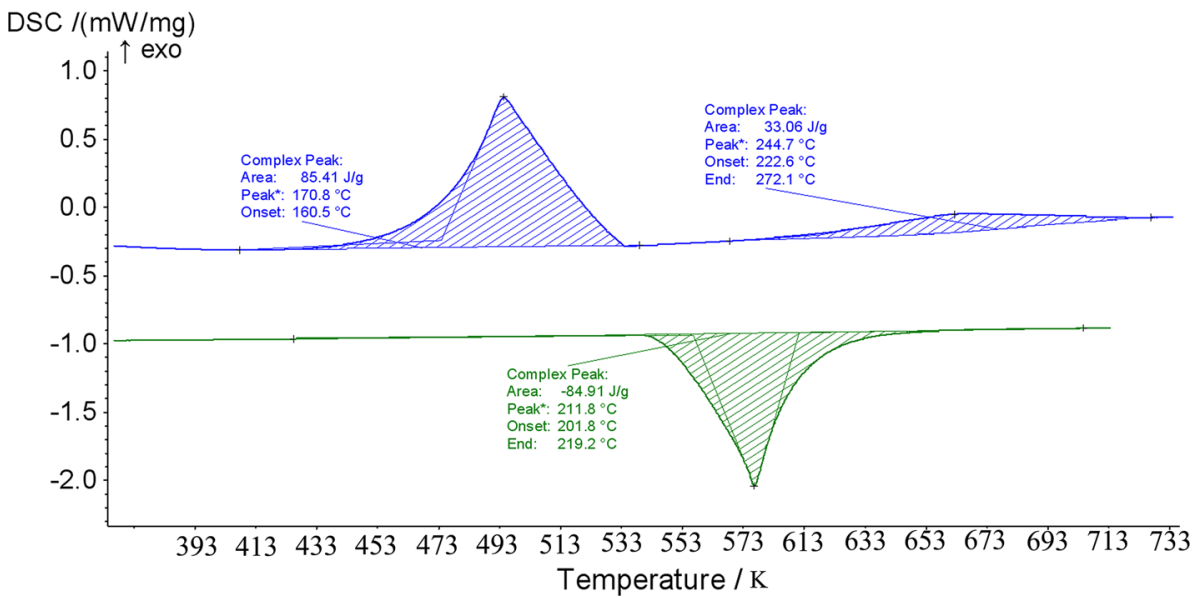

Fig. 1. (a) Spreading area of Sn-Zn0.5Ga and Sn-Zn0.2Na alloys on Al substrate, with time and temperature dependency, (b) Calorimetry study for Sn-Zn0.2Na alloy.

rate and $\mathrm{Zn}$ content affect the $\mathrm{Zn}$ morphology, IMC formation, its distribution throughout the bulk and, consequently, the final wettability and mechanical properties. ${ }^{37-39}$ The model of dissolving $\mathrm{Al}$ by $\mathrm{Sn}$ was presented in Ref. 24, which shows the $\mathrm{Al}$ substrate dissolving in several steps. First, the oxide is removed from the base aluminum, then the aluminum substrate begins to dissolve in the Sn solder. After this, dissolution of $\mathrm{Al}$ occurs preferentially at grain boundaries near the interface. As time increases, the grains freed from their boundaries migrate into the solder. Finally, the precipitated aluminum that was previously dissolved in $\mathrm{Sn}$ is dissolved further by the surrounding Sn solder, and the migrated grains become aluminum dendrites. ${ }^{24}$ The same effect is observed for the Sn-Zn0.5Ga alloy. For the Sn$\mathrm{Zn} 0.2 \mathrm{Na}$ alloy, the zone of the dissolved $\mathrm{Al}$ layer (points 28, 32, 33) is near the interface. Particles of dissolving $\mathrm{Al}$ are observed inside the drop of solder for both alloys, similar to the results presented in the literature ${ }^{24}$ and a previous study. 8,30

\section{The Spreading Test on Ni Substrate}

Figure 4 shows the spreading area of $\mathrm{Sn}-\mathrm{Zn} 0.5 \mathrm{Ga}$ and $\mathrm{Sn}-\mathrm{Zn} 0.2 \mathrm{Na}$ on the $\mathrm{Ni}$ substrate. For both alloys, the spreading area value obtained was for $1 \mathrm{~min}$ of soldering at all temperatures. With increasing time, the spreading area reduced at all temperatures, and the lowest level was obtained for $8 \mathrm{~min}$. For the Sn-Zn0.5Ga alloy at $503 \mathrm{~K}$ and $523 \mathrm{~K}$ $\left(230^{\circ} \mathrm{C}\right.$ and $250^{\circ} \mathrm{C}$, respectively), a high spreading area value was obtained for up to $3 \mathrm{~min}$. However, at $553 \mathrm{~K}\left(280^{\circ} \mathrm{C}\right)$ this was true only for $1 \mathrm{~min}$, and after that, the spreading area reduced. The same situation was observed for the $\mathrm{Sn}-\mathrm{Zn} 0.2 \mathrm{Na}$ alloy at all temperatures. This is caused by the $\gamma-\mathrm{Ni}_{5} \mathrm{Zn}_{21}$ phase layer formed at the interface (Figs. 5 and 6 ), 

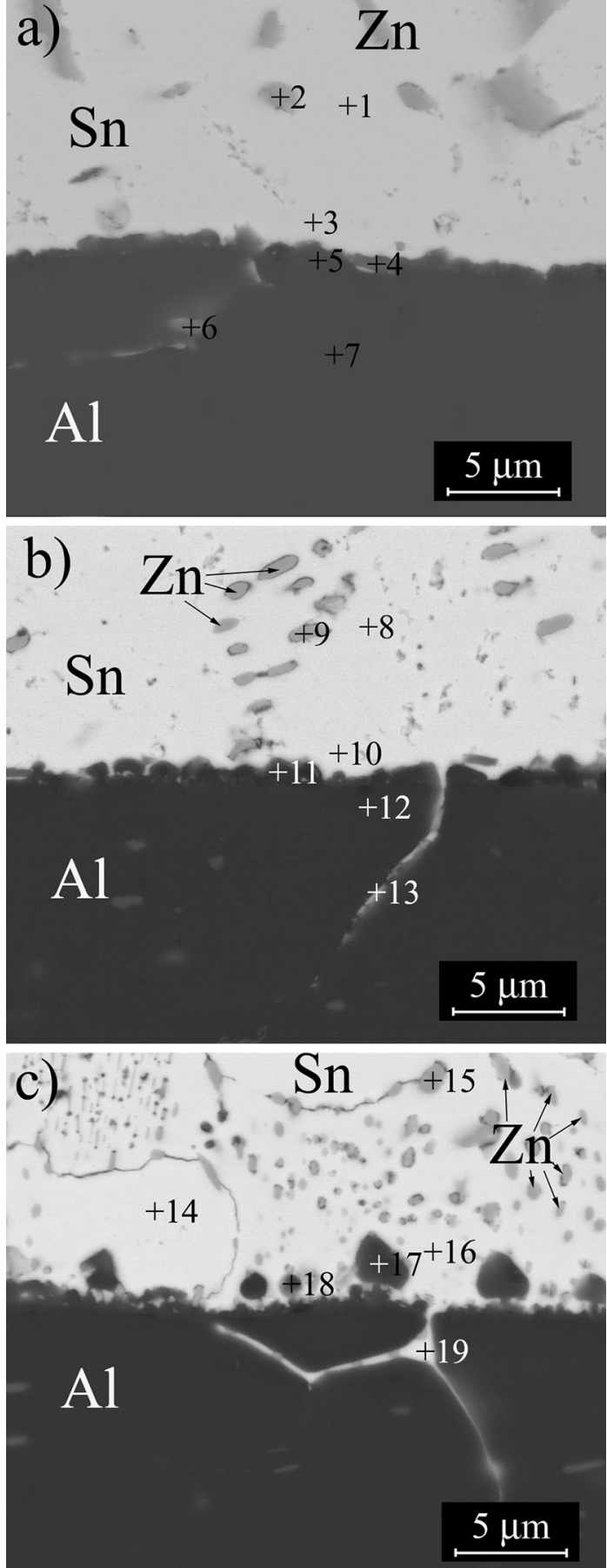

Fig. 2. Microstructure of cross section of liquid solder $\mathrm{Sn}-\mathrm{Zn} 0.5 \mathrm{Ga}$ on Al substrate at $503 \mathrm{~K}\left(230^{\circ} \mathrm{C}\right)$ and over times of (a) 1 , (b) 3 and (c) $8 \mathrm{~min}$.

resulting in changes to the interface condition. In the first step of the soldering process, the spreading area of liquid alloys on $\mathrm{Ni}$ substrate and, after time, the liquid alloys on the $\mathrm{Ni}_{5} \mathrm{Zn}_{21}$ phase were observed (Fig. 5). The changes of chemical composition of the substrate caused a reduction in the spreading area, which was also observed in the contact angle. ${ }^{11}$
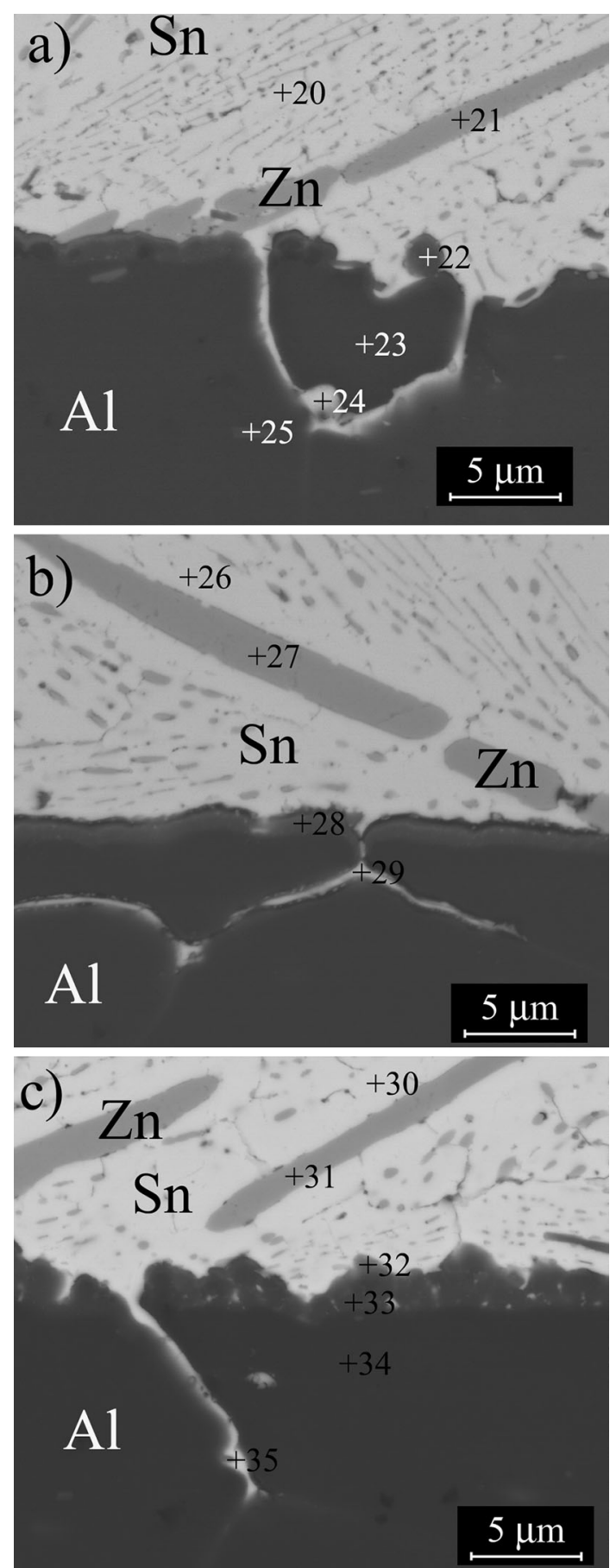

Fig. 3. Microstructure of cross section of liquid solder $\mathrm{Sn}-\mathrm{Zn} 0.2 \mathrm{Na}$ alloy on Al substrate for a time of $8 \mathrm{~min}$ and at temperatures of (a) $503 \mathrm{~K}\left(230^{\circ} \mathrm{C}\right)$, (b) $523 \mathrm{~K}\left(250^{\circ} \mathrm{C}\right)$, and (c) $553 \mathrm{~K}\left(280^{\circ} \mathrm{C}\right)$.

Huang et al. ${ }^{11}$ also observed a reducing contact angle with increased $\mathrm{Ag}$ content, caused by the $\mathrm{Zn}$ with $\mathrm{Ag}$ connection in the formed $\mathrm{Ag}_{3} \mathrm{Zn}$ phase precipitates, and which resulted in a reduced amount of free $\mathrm{Zn}$ that could diffuse to the interface. Comparing the spreading area of Sn-Zn0.5Ga and $\mathrm{Sn}-\mathrm{Zn} 0.2 \mathrm{Na}$ alloys on $\mathrm{Ni}$ substrate with these same 
Table I. The EDS analysis of Sn-Zn0.5 Ga on Al substrate marked at Fig. 2

\begin{tabular}{|c|c|c|c|c|}
\hline & $\mathbf{A l ^ { \mathrm { K } }}$ & $\mathbf{S n}^{\mathbf{L}}$ & $\mathbf{Z n}^{\mathrm{K}}$ & $\mathbf{G a}^{\mathrm{K}}$ \\
\hline 1 & 0 & 98.9 & 0.6 & 0.5 \\
\hline 2 & 0.3 & 41.8 & 56.5 & 1.4 \\
\hline 3 & 0.9 & 98.4 & 0.2 & 0.5 \\
\hline 4 & 66.2 & 29.3 & 3.9 & 0.6 \\
\hline 5 & 77.6 & 16.2 & 5.5 & 0.7 \\
\hline 6 & 74.8 & 23.8 & 0.9 & 0.5 \\
\hline 7 & 99.6 & 0.3 & 0.1 & 0 \\
\hline 8 & 0.7 & 97.5 & 0.9 & 0.9 \\
\hline 9 & 0.4 & 36.8 & 61.4 & 1.4 \\
\hline 10 & 2.4 & 96.1 & 0.7 & 0.8 \\
\hline 11 & 45 & 31.6 & 22.3 & 1.1 \\
\hline 12 & 95.1 & 3.8 & 0.7 & 0.4 \\
\hline 13 & 75.8 & 22.5 & 1.4 & 0.3 \\
\hline 14 & 0.2 & 98.3 & 0.7 & 0.8 \\
\hline 15 & 0.2 & 18.6 & 79.3 & 1.9 \\
\hline 16 & 0.3 & 97.9 & 1.4 & 0.4 \\
\hline 17 & 50 & 38.5 & 11.4 & 0.1 \\
\hline 18 & 87.6 & 10.7 & 1.4 & 0.3 \\
\hline 19 & 20.4 & 77.8 & 1.3 & 0.5 \\
\hline
\end{tabular}

Table II. The EDS analysis of Sn-Zn0.2Na alloy on Al substrate marked at Fig. 3

\begin{tabular}{lccr}
\hline & $\mathbf{A l}^{\mathbf{K}}$ & $\mathbf{S n}^{\mathbf{L}}$ & $\mathbf{Z n}^{\mathbf{K}}$ \\
\cline { 2 - 3 } 20 & 0.1 & 97.6 & 2.3 \\
21 & 0.4 & 6.5 & 93.1 \\
22 & 43.1 & 43.5 & 13.4 \\
23 & 99 & 0.8 & 0.2 \\
24 & 41.5 & 57.4 & 1.1 \\
25 & 99.3 & 0.5 & 0.2 \\
26 & 0.9 & 97.6 & 1.5 \\
27 & 0.4 & 2 & 97.6 \\
28 & 68.7 & 14.1 & 17.2 \\
29 & 36.5 & 60.6 & 2.9 \\
30 & 0.2 & 98.3 & 1.5 \\
31 & 0.6 & 8.5 & 90.9 \\
32 & 37.5 & 50.8 & 11.7 \\
33 & 80 & 8.4 & 11.6 \\
34 & 99.3 & 0.5 & 0.2 \\
35 & 41.4 & 57.3 & 1.3 \\
\hline
\end{tabular}

alloys on $\mathrm{Cu}$ substrate, ${ }^{21,22}$ there was no such significant reduction of spreading area over time, although a $\mathrm{Cu}_{5} \mathrm{Zn}_{8}$ phase layer formed at the interface. This is accounted for by the much greater effect of the IMC layers on the spreading area in the soldering process on $\mathrm{Ni}$ substrate, compared to $\mathrm{Cu}$.

In the case of the $\mathrm{Sn}-\mathrm{Zn} 0.5 \mathrm{Ga}$ alloy, the microstructure of the cross section on a Ni substrate at $503 \mathrm{~K}\left(230^{\circ} \mathrm{C}\right)$ for times of $1 \mathrm{~min}, 3 \mathrm{~min}$ and $8 \mathrm{~min}$ is shown in Fig. 5, and EDS analysis is presented in Table III. The Ga content dissolved in the Sn-Zn matrix and did not create an IMC with Sn and $\mathrm{Zn}$. In the presented XRD analysis (Fig. 5d) of the $\mathrm{Sn}-\mathrm{Zn} 0.5 \mathrm{Ga}$ alloy on $\mathrm{Ni}$ substrate at $553 \mathrm{~K}$

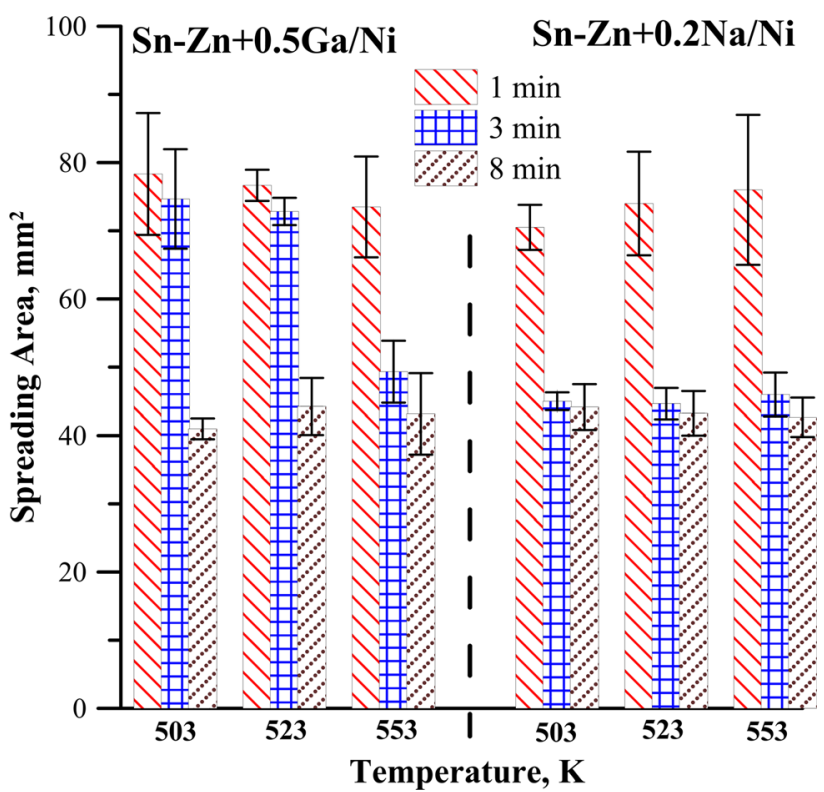

Fig. 4. Spreading area of $\mathrm{Sn}-\mathrm{Zn} 0.5 \mathrm{Ga}$ and $\mathrm{Sn}-\mathrm{Zn} 0.2 \mathrm{Na}$ alloys on $\mathrm{Ni}$ substrate, with time and temperature dependency.

$\left(280^{\circ} \mathrm{C}\right)$ and for a time of $8 \mathrm{~min}, \mathrm{a} \mathrm{Ni}_{5} \mathrm{Zn}_{21}$ phase [the chemical composition is confirmed by EDS analysis (point 45), the amount of $\mathrm{Sn}$ is shown because the IMC layer is very thin, which has an impact on the value obtained from the EDS method] was found at the interface. The EDS analysis presented in Table III shows that the Ga content was dissolved in the entire volume of solder, but also indicates a higher amount occurring at the interface of solder/substrate (points 41 and 45). With increasing time, the morphology of $\mathrm{Zn}$ precipitates changed, starting from small thin needles which reduced in number and grew after $8 \mathrm{~min}$. The $\mathrm{Zn}$ diffused to the interface and formed a $\mathrm{Ni}_{5} \mathrm{Zn}_{21}$ phase in the cases of both the $\mathrm{Sn}-\mathrm{Zn} 0.5 \mathrm{Ga}$ and $\mathrm{Sn}-\mathrm{Zn} 0.2 \mathrm{Na}$ alloys. A similar effect of creating a $\mathrm{Ni}_{5} \mathrm{Zn}_{21}$ layer at the interface was observed in Refs. 11-18. In the case of $\mathrm{Ag}^{11}$ and $\mathrm{Cu}^{18}$ additions, additional IMCs occurred at the interface $\left(\mathrm{AgZn}_{3}\right.$ and $\mathrm{Cu}_{5} \mathrm{Zn}_{8}$, respectively). Ga content dissolved in $\mathrm{Al}$ and $\mathrm{Zn}$, but $\mathrm{Ga}$ with $\mathrm{Ni}$ created an IMC, as shown in the phase diagram of the Ga-Ni system. ${ }^{40}$ However, the limited amount of $\mathrm{Ga}$, the temperature of the soldering process and the value of Gibbs energy: for $\varepsilon-\mathrm{NiGa}_{3}, \gamma-\mathrm{Ni}_{3} \mathrm{Ga}_{2}$ and $\delta-\mathrm{Ni}_{5} \mathrm{Ga}_{3}$ do not suggest IMCs from the Ga-Ni system, as opposed to $\gamma-\mathrm{Ni}_{5} \mathrm{Zn}_{21}$ and $\delta-\mathrm{Ni}_{2} \mathrm{Zn}_{15}$ from the Ni-Zn system. Neither do the EDS (points and linescan) and XRD analysis show an IMC from the Ga-Ni or $\mathrm{Sn}-\mathrm{Ni}$ system, but only confirm the occurrence of IMCs from the $\mathrm{Ni}-\mathrm{Zn}$ system.

Figure 6 shows the microstructure of a cross section of liquid solder $\mathrm{Sn}-\mathrm{Zn} 0.2 \mathrm{Na}$ on $\mathrm{Ni}$ substrate for a time of $8 \mathrm{~min}$, at temperatures of (a) $503 \mathrm{~K}$ $\left(230^{\circ} \mathrm{C}\right)$, (b) $523 \mathrm{~K}\left(250^{\circ} \mathrm{C}\right)$ and (c) $553 \mathrm{~K}\left(280^{\circ} \mathrm{C}\right)$ and (d) XRD analysis. The EDS analysis, performed in 

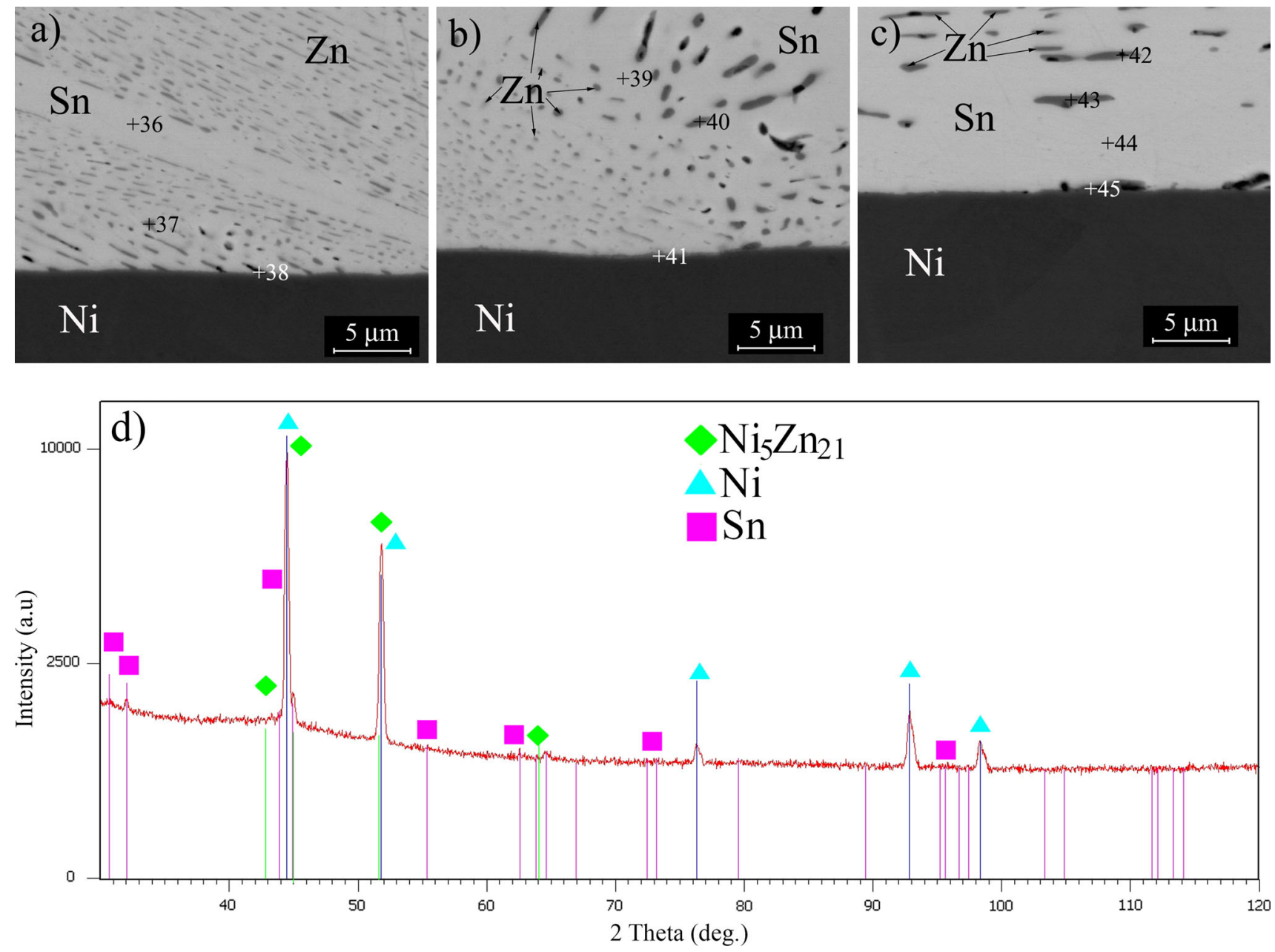

Fig. 5. Microstructure of cross section of liquid solder Sn-Zn0.5Ga on Ni substrate at $503 \mathrm{~K}\left(230^{\circ} \mathrm{C}\right)$ and over times of (a) 1 , (b) 3 and (c) 8 min and (d) XRD analysis.

the place marked on Fig. 6, is presented in Table IV. Taking into account that the $\mathrm{Na}$ cannot be detected using EDS, analysis for $\mathrm{Sn}, \mathrm{Ni}$ and $\mathrm{Zn}$ was presented in Table IV. The highest value of Ni for EDS analysis (points 52 and 56) was obtained at the interface. This was caused by the IMC layer created at the interface of the solder/Ni substrate, the same as in the case of Sn-Zn0.5Ga. However, for the Sn$\mathrm{Zn} 0.2 \mathrm{Na}$ alloy, the observed $\mathrm{Zn}$ particles were dispersed compared to the single $\mathrm{Zn}$ needles observed (Fig. 5) in the Sn-Zn0.5Ga alloy. Furthermore, the microstructure of $\mathrm{Sn}-\mathrm{Zn}$ with $\mathrm{Na}$ on $\mathrm{Ni}$ substrate was different compared to this solder on $\mathrm{Al}$ substrate, as the huge needles of $\mathrm{Zn}$ that are observed when soldering on $\mathrm{Al}$ substrate (Fig. 3) are not apparent. With increasing temperature of soldering on Ni substrate, the growth of the IMC layer at the interface was observed for $\mathrm{Sn}-\mathrm{Zn} 0.2 \mathrm{Na}$, similar to the Sn-Zn0.5Ga alloy. The greatest IMC thickness was obtained for the longest time ( $8 \mathrm{~min})$ at each temperature. However, a different character of IMC layer growth at the interface was observed for Sn-Zn0.2Na and Sn-Zn0.5Ga alloys on $\mathrm{Ni}$ substrate. For the Sn-Zn0.5Ga alloy, the layer grew continuously over time, with local maximums and minimums, resulting in growth characterized by diffusion. For the Sn-Zn0.2Na alloy, a thin IMC layer and large IMC particles of the $\mathrm{Ni}_{5} \mathrm{Zn}_{21}$ phase formed at the interface during soldering. An IMC from the Ni-Sn system was also identified, using XRD. The XRD was confirmed using synchrotron measurements (SR-XRD), and the results obtained are presented in Fig. 6e. The obtained data show the occurrence of $\mathrm{Ni}_{5} \mathrm{Zn}_{21}, \mathrm{Ni}_{3} \mathrm{Sn}_{4}, \mathrm{Ni}_{3} \mathrm{Sn}_{2}$ and $\mathrm{NaZn}_{13}$ phases, and also of pure elements $\mathrm{Sn}, \mathrm{Ni}$ and $\mathrm{Zn}$. For obtaining crystallographic data with the goal of identifying the phases, the crystal structure for $\mathrm{Ni}_{5} \mathrm{Zn}_{21}$ was taken from Ref. 41, $\mathrm{Ni}_{3} \mathrm{Sn}_{4}$ from Ref. 42, $\mathrm{Ni}_{3} \mathrm{Sn}_{2}$ from Ref. 43 and $\mathrm{NaZn}_{13}$ from Ref. 44. The occurring $\mathrm{NaZn}_{13}$ phase precipitates were also identified in cast solder. ${ }^{22}$ Analyzed data showed, after pure elements Sn, Ni and $\mathrm{Zn}$, the highest amount for the $\mathrm{Ni}_{5} \mathrm{Zn}_{21}$ phase, then the $\mathrm{Ni}_{3} \mathrm{Sn}_{4}, \mathrm{Ni}_{3} \mathrm{Sn}_{2}$ and $\mathrm{NaZn}_{13}$ phases, respectively. The occurrence of phases from the Sn-Ni system and not only the $\mathrm{Ni}_{5} \mathrm{Zn}_{21}$ layer at the 

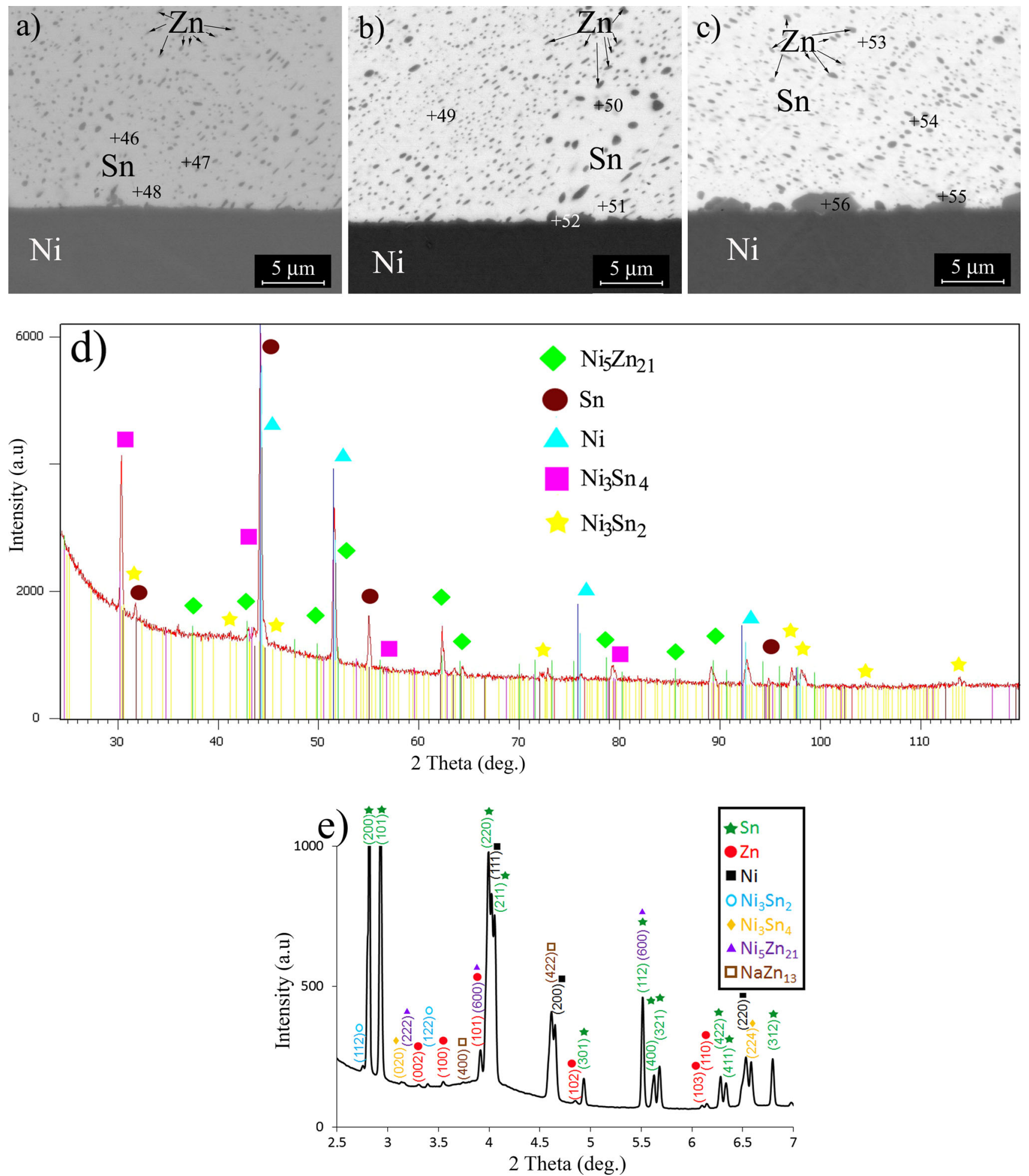

Fig. 6. Microstructure of cross section of liquid solder $\mathrm{Sn}-\mathrm{Zn} 0.2 \mathrm{Na}$ on Ni substrate for a time of 8 min and at temperatures of (a) $503 \mathrm{~K}\left(230^{\circ} \mathrm{C}\right)$, (b) $523 \mathrm{~K}\left(250^{\circ} \mathrm{C}\right)$ and (c) $553 \mathrm{~K}\left(280^{\circ} \mathrm{C}\right)$, (d) XRD analysis and (e) SR-XRD result.

interface is correlated with the occurrence of $\mathrm{NaZn}_{13}$ precipitates in solder, which reduce the amount of free $\mathrm{Zn}$ in the alloy able to diffuse to the interface and create an IMC layer. Liuo et al. ${ }^{18}$ made a similar observation for the phase with Sn, in the case of $\mathrm{Sn}-\mathrm{Zn}$ with $\mathrm{Cu}$ on $\mathrm{Ni}$ substrate, but a $\mathrm{Ni}_{5} \mathrm{Zn}_{21}$ phase layer is created at the interface only for 1 (wt.\%) $\mathrm{Cu}$ content. This was caused by the formation of $\mathrm{Cu}_{5} \mathrm{Zn}_{8}$ phase precipitates in the alloys, which resulted in the connection of free $\mathrm{Zn}$ with $\mathrm{Cu}$. 
Table III. The EDS analysis of Sn-Zn0.5Ga on Ni substrate marked at Fig. 5

\begin{tabular}{lcrrr}
\hline & $\mathbf{S n}^{\mathbf{L}}$ & $\mathbf{N i}^{\mathbf{K}}$ & $\mathbf{Z n}^{\mathbf{K}}$ & \\
\cline { 2 - 3 } 36 & 96.7 & 1.1 & 1.5 & $\frac{\mathbf{G a}^{\mathbf{K}}}{0.7}$ \\
37 & 63.6 & 1.3 & 34.2 & 0.9 \\
38 & 73 & 13.1 & 13.1 & 0.8 \\
39 & 98.2 & 0.4 & 0.6 & 0.8 \\
40 & 50.3 & 0.4 & 48.1 & 1.2 \\
41 & 30.2 & 27.4 & 40.2 & 2.2 \\
42 & 49.9 & 0.5 & 48.8 & 0.8 \\
43 & 0.4 & 98.9 & 0.4 & 0.3 \\
44 & 97 & 1.7 & 0.6 & 0.7 \\
45 & 16.2 & 17.7 & 63.9 & 2.2 \\
\hline
\end{tabular}

Table IV. The EDS analysis of Sn-Zn0.2Na alloy on Ni substrate marked at Fig. 6

\begin{tabular}{lccc}
\hline & $\mathbf{S n}^{\mathbf{L}}$ & $\mathbf{N i}^{\mathbf{K}}$ & $\mathbf{Z n}^{\mathbf{K}}$ \\
\cline { 2 - 3 } & 94.3 & 1.2 & 4.5 \\
47 & 56.4 & 1.3 & 42.3 \\
48 & 91.4 & 2 & 6.6 \\
49 & 94.6 & 1 & 4.4 \\
50 & 44.4 & 0.2 & 55.4 \\
51 & 93 & 2.4 & 4.6 \\
52 & 15.6 & 18.3 & 66.1 \\
53 & 93.4 & 0.9 & 5.7 \\
54 & 61.6 & 0.4 & 38 \\
55 & 47.4 & 2.8 & 49.8 \\
56 & 15.1 & 14.5 & 70.4 \\
\hline
\end{tabular}

Taking into account that the $\mathrm{Na}$ content formed with $\mathrm{Zn}$ the precipitates of the $\mathrm{NaZn}_{13}$ phase, even such a small addition $(0.2$ (wt.\%)) of $\mathrm{Na}$ caused the formation of phases from the Ni-Sn system, which was not observed in the case of the Sn-Zn0.5Ga alloy. The effect of $\mathrm{Zn}$ content was studied in Refs. 15 and 17 for soldering Sn-Zn alloy on Ni substrate at $523 \mathrm{~K}\left(250^{\circ} \mathrm{C}\right)$. It was found that 9 (wt.\%) $\mathrm{Zn}$ caused the formation of a stable $\mathrm{Ni}_{5} \mathrm{Zn}_{21}$ phase at the interface, but $\mathrm{Zn}$ below 9 (wt.\%) caused the creation of a phase from the Ni-Sn system. This was due to the soldering process, where, in the beginning, when the liquid alloy dissolved the $\mathrm{Ni}$ substrate, the $\mathrm{Zn}$ easily formed a $\mathrm{Ni}_{5} \mathrm{Zn}_{21}$ phase. However, as the reaction layer increased to a certain thickness, $\mathrm{Zn}$ diffusion through the IMC layer became dominant. The intrinsic diffusion coefficient of $\mathrm{Zn}$ compared to $\mathrm{Ni}$ was similar for the $\mathrm{Ni}_{5} \mathrm{Zn}_{21}$ phase, and in Ref. 15 was calculated for $523 \mathrm{~K}\left(250^{\circ} \mathrm{C}\right)$ to be $9.66 \times 10^{-15}\left(\mathrm{~m}^{2} / \mathrm{s}\right)$ for $\mathrm{Zn}$ and $3.86 \times 10^{-16}\left(\mathrm{~m}^{2} / \mathrm{s}\right)$ for $\mathrm{Ni}$. During the soldering process, the diffusion of $\mathrm{Ni}$ to the interface at a specified temperature should be stable for all cases. Taking into account that the thickness of the $\mathrm{Ni}_{5} \mathrm{Zn}_{21}$ layer is correlated with the amount of $\mathrm{Zn}$ in the solder, the additions that formed with $\mathrm{Zn}$ IMCs, as $\mathrm{Na}$, could reduce the growth rate of the
$\mathrm{Ni}_{5} \mathrm{Zn}_{21}$ layer. That is why the thickness of the $\mathrm{Ni}_{5} \mathrm{Zn}_{21}$ layer obtained for $\mathrm{Sn}-\mathrm{Zn} 0.5 \mathrm{Ga}$ is greater compared to $\mathrm{Sn}-\mathrm{Zn} 0.2 \mathrm{Na}$. However, as shown by XRD and confirmed by synchrotron measurements, not only a $\mathrm{Ni}_{5} \mathrm{Zn}_{21}$ layer occurred at the interface, as in the case $\mathrm{Sn}-\mathrm{Zn} 0.5 \mathrm{Ga}$, but $\mathrm{Ni}_{3} \mathrm{Sn}_{4}$ and $\mathrm{Ni}_{3} \mathrm{Sn}_{2}$ phases were also detected for soldering $\mathrm{Sn}-\mathrm{Zn} 0.2 \mathrm{Na}$ on Ni substrate. A similar observation was made for Sn1.0Zn (wt.\%) alloys, ${ }^{15}$ where an Sn-Ni IMC layer formed at the interface. This is correlated with lower $\mathrm{Zn}$ content in the alloy.

The comparative thicknesses of IMCs at the interface for $\mathrm{Sn}-\mathrm{Zn} 0.5 \mathrm{Ga}$ and $\mathrm{Sn}-\mathrm{Zn} 0.2 \mathrm{Na}$ alloys are presented in Fig. 7a. For all temperature and time dependencies, the thickness of the $\mathrm{Ni}_{5} \mathrm{Zn}_{21}$ layer for Ga content was slightly higher compared to Na. Taking into account the thickness of the $\mathrm{Ni}_{5} \mathrm{Zn}_{21}$ phase layer over time, the parameter " $n$ " is obtained. The character and rate of growth are correlated to parameter " $n$ " as a coefficient of growth, where $n \ll 0.5$ is grain boundary, $n=0.5$ is volume diffusion and $n=1$ is chemical reaction. From the obtained $n$ parameter for the $\mathrm{Sn}-\mathrm{Zn} 0.5 \mathrm{Ga}$ and $\mathrm{Sn}-\mathrm{Zn} 0.2 \mathrm{Na}$ alloys, the $\mathrm{Ni}$ substrate dissolves through a grain boundary process. The $n$ value is 0.38 and 0.33 for $503 \mathrm{~K}\left(230^{\circ} \mathrm{C}\right), 0.33$ and 0.29 for $523 \mathrm{~K}\left(250^{\circ} \mathrm{C}\right)$ and with increasing temperature to $553 \mathrm{~K}\left(280^{\circ} \mathrm{C}\right)$, reduces to 0.28 and 0.23 for Sn$\mathrm{Zn} 0.2 \mathrm{Na}$ and Sn-Zn0.5Ga, respectively. The value of $n$ corresponded to grain boundary dissolution. This was caused by small grain size, deep grooves between grains and the temperature of the soldering process, which was much lower than the melting temperature of the IMC layer. This led to grain boundary diffusion being the predominant mechanism for transport through the layers. ${ }^{45}$ The same character of changes, with the value for parameter $n$ reducing as temperature increased, was observed in Ref. 15. There are two possible explanations for the slightly lower exponent $n$ observed in the experiment. First, in the derivation, it was assumed that grain boundary diffusion predominates and volume diffusion could be ignored. ${ }^{45}$ At some point, the intermetallic grain size will grow large enough and the grain boundary area will reduce sufficiently to allow volume diffusion to take over as the predominant transport mechanism. This transition to a slower transport mechanism will tend to flatten out the latter part of the growth curve. As a result, the indicated growth exponent would be lower. ${ }^{45}$ Second, the observed grain shapes seem to change slightly from spherical to more elongated ellipsoidal shapes as the layer grows in thickness. This could influence the relative contribution of grain boundary diffusion. The relative depth of the channels may change over time. ${ }^{45}$ This is related to the amount of Ni substrate dissolving in the first step of soldering with increasing temperature, leading to a swiftly forming $\mathrm{Ni}_{5} \mathrm{Zn}_{21}$ phase layer at the interface. The values of $n$ in Ref. 15 are slightly higher, but the experiment was conducted over a longer time 
(up to $48 \mathrm{~h}$ ), and the authors ${ }^{15}$ used a different method, describing the experimental data by a logarithm scale for obtaining the $n$ and $k$ parameters. The obtained ${ }^{12,15}$ IMC thicknesses over a short time are similar to this study. These thicknesses were $0.632 \mu \mathrm{m}$ for $\mathrm{Sn} 11.1 \mathrm{Zn}{ }^{12}$ and $0.591 \mu \mathrm{m}$ for $\mathrm{Sn} 9.0 \mathrm{Zn}$ for $600 \mathrm{~s}^{15}$ to $0.441 \mu \mathrm{m}$ for $\mathrm{Sn}-\mathrm{Zn} 0.2 \mathrm{Na}$ and 0.454 for $\mathrm{Sn}-\mathrm{Zn} 0.5 \mathrm{Ga}$ for $480 \mathrm{~s}$ at a temperature of $523 \mathrm{~K}\left(250^{\circ} \mathrm{C}\right)$. However, $1.26 \mathrm{Bi}$ and $0.34 \mathrm{P}$ were added to the Sn11.1Zn alloy in Ref. 12, which could have an effect on IMC thickness at the interface, although obtained thicknesses do not indicate this. Comparing the thickness of the IMC layer on $\mathrm{Ni}$ with the $\mathrm{Cu}$ substrate shows that, even for $60 \mathrm{~s}$, the thickness on the $\mathrm{Cu}$ substrate was one order of magnitude higher compared to the Ni substrate for $\mathrm{Sn}-\mathrm{Zn} 0.5 \mathrm{Ga}^{21}$ and $\mathrm{Sn}-\mathrm{Zn} 0.2 \mathrm{Na}^{22}$ alloys, and with increasing time the difference also increases. This difference results from the melting temperature of $\mathrm{Ni}$, diffusion, the stability of formed phases and other factors. The obtained kinetic parameter as growth rate $k$ (see Table V) was used in the Arrhenius equation to calculate activation energy $Q$, which is presented in Fig. 7b. The activation energy was $52.9(\mathrm{~kJ} / \mathrm{mol})$ for Sn-Zn0.5Ga and 55.1 $(\mathrm{kJ} / \mathrm{mol})$ for $\mathrm{Sn}-\mathrm{Zn} 0.2 \mathrm{Na}$, which corresponds to the obtained thickness of the $\mathrm{Ni}_{5} \mathrm{Zn}_{21}$ layer and the manner in which $\mathrm{Ga}$ and $\mathrm{Na}$ are connected with $\mathrm{Zn}$. The obtained results correspond well to those in Ref. $15(55.0(\mathrm{~kJ} / \mathrm{mol})$ for $\mathrm{Sn} 7.0 \mathrm{Zn}$ and $47.2(\mathrm{~kJ} / \mathrm{mol})$ for Sn9.0Zn). A much higher value was obtained in Ref. $46[112.5(\mathrm{~kJ} / \mathrm{mol})$ for $\mathrm{Sn} 9.0 \mathrm{Zn}]$, but this was caused by the introduction of an intermediate $\mathrm{Au}$ layer, which caused a delay in the formation of the $\mathrm{Ni}_{5} \mathrm{Zn}_{21}$ layer by the time taken for the dissolution of the $\mathrm{Au}$ layer.

Based on experimental work presented in Ref. 15, the $\mathrm{Zn}$ atoms would tend to diffuse toward the interface and then react with $\mathrm{Ni}$ to form the $\mathrm{Ni}_{5} \mathrm{Zn}_{21}$ in the $\mathrm{Sn}-\mathrm{Zn} / \mathrm{Ni}$ interfacial reactions. The main factor of growth of the $\mathrm{Ni}_{5} \mathrm{Zn}_{21}$ phase is the amount of $\mathrm{Zn}$ in the alloys. The growth of the $\mathrm{Ni}_{5} \mathrm{Zn}_{21}$ layer is controlled by the diffusion of $\mathrm{Zn}$ to the formed layer at the interface. The increasing temperature and higher amount of $\mathrm{Zn}$ caused an increasing rate of growth of the IMC layer, resulting in the decrease of activation energy of the chemical reaction. ${ }^{15}$ As shown in Ref. 15, with increasing Zn content, the Zn atoms participating in the chemical transformation at the interface would presumably increase, which could favor the nucleation and growth of $\mathrm{Ni}_{5} \mathrm{Zn}_{21}$. However, for the $\mathrm{Sn}-\mathrm{Zn} / \mathrm{Ni}$ interfacial reaction, $\mathrm{Ni}_{5} \mathrm{Zn}_{21}$ growth depends on the $\mathrm{Zn}$ supply from the solder. Therefore, with increasing time, the $\mathrm{Zn}$ diffused to the $\mathrm{Ni}_{5} \mathrm{Zn}_{21}$ layer, causing the formation of the $\mathrm{Zn}$ depletion region above the interface. As was shown in Ref. 18, the lower the $\mathrm{Zn}$ content, the wider the $\mathrm{Zn}$ depletion region. The $\mathrm{Zn}$ content in the $\mathrm{Sn}-\mathrm{Zn}$ alloy has a decisive effect on the formation of IMCs at the interface. For 1.0 (wt.\%) $\mathrm{Zn}$ at the interface, a $\mathrm{Ni}_{5} \mathrm{Zn}_{21}$ phase was created, but with
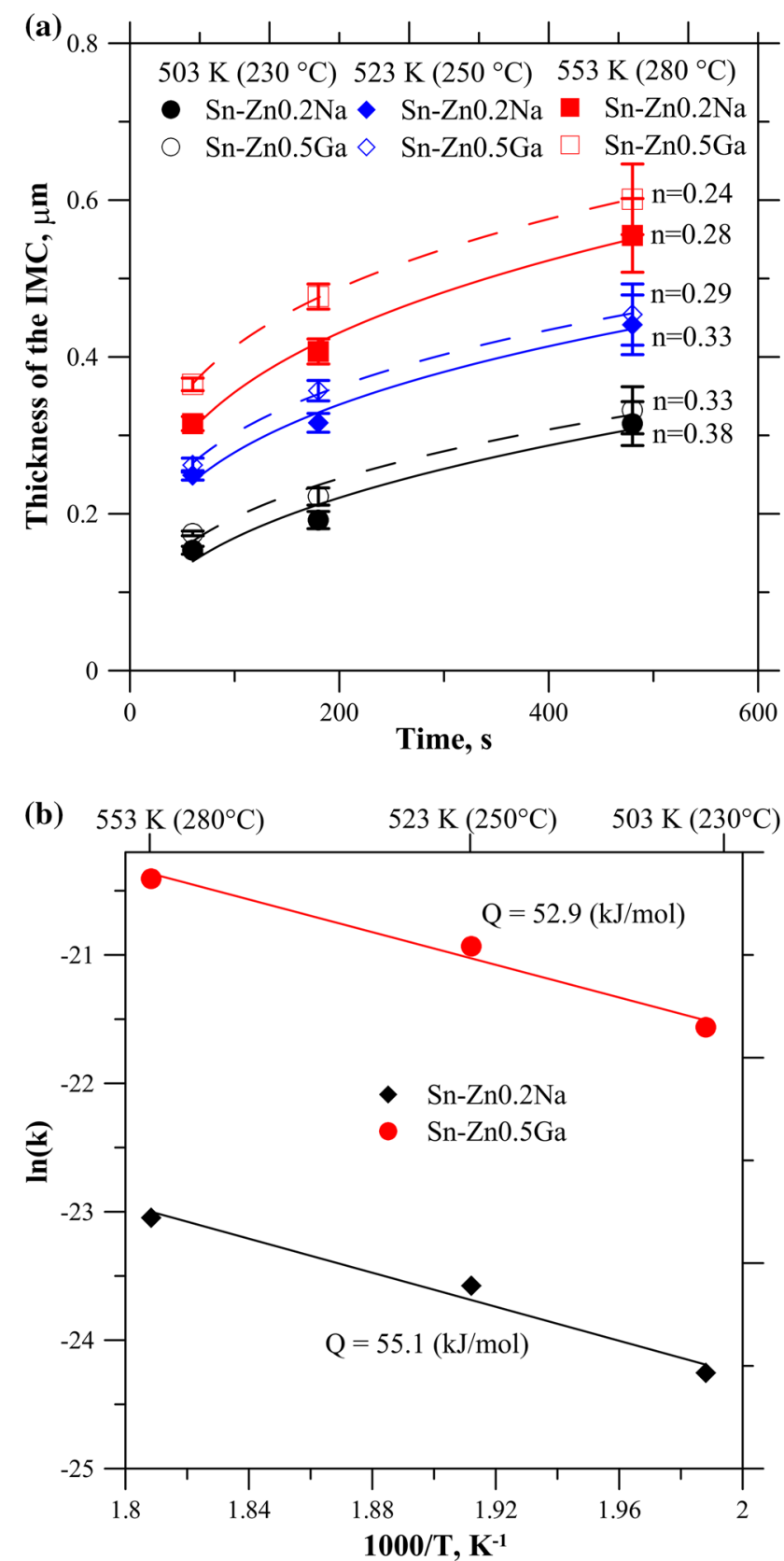

Fig. 7. The calculated (a) thickness of the IMC at interface versus time, (b) activation energy for Sn-Zn0.5Ga and Sn-Zn0.2Na alloys.

increasing time and diffusion of $\mathrm{Ni}$ to the solder, this small amount of $\mathrm{Zn}$ caused the formation of IMCs from Ni-Sn and Ni-Sn-Zn systems. However, upon increasing $\mathrm{Zn}$ content to 3.0 (wt.\%), $\mathrm{Zn}$ at the interface formed a $\mathrm{Ni}_{5} \mathrm{Zn}_{21}$ layer and this, with increasing time, grew, which indicates that this amount of $\mathrm{Zn}$ is sufficient to balance $\mathrm{Ni}$ diffusion. Furthermore, the activation energy of diffusion for the formation of $\mathrm{Ni}_{5} \mathrm{Zn}_{21}$ could be attributed to the energy barriers of atomic diffusion processes. That is why the activation energy for $\mathrm{Ni}_{5} \mathrm{Zn}_{21}$ was higher for the Sn3.0Zn alloy compared to Sn9.0Zn. ${ }^{17}$ In the first step of dissolving the $\mathrm{Ni}$ substrate, after the 
Table V. The $\mathrm{Ni}_{5} \mathrm{Zn}_{21}$ phase growth kinetic parameters and the corresponding activation energies obtained during soldering on Ni substrate by liquid Sn-Zn0.5Ga and Sn-Zn0.2Na alloys

\begin{tabular}{|c|c|c|c|c|c|}
\hline \multirow[b]{2}{*}{ Alloys } & \multicolumn{3}{|c|}{$k(\mathbf{m} / \mathbf{s})$} & \multirow[b]{2}{*}{$k_{0}(\mathbf{m} / \mathbf{s})$} & \multirow[b]{2}{*}{$\boldsymbol{Q}(\mathbf{k J} / \mathbf{m o l})$} \\
\hline & $503 \mathrm{~K}\left(230^{\circ} \mathrm{C}\right)$ & $523 \mathrm{~K}\left(250^{\circ} \mathrm{C}\right)$ & $553 \mathrm{~K}\left(280^{\circ} \mathrm{C}\right)$ & & \\
\hline $\mathrm{Sn}-\mathrm{Zn} 0.2 \mathrm{Na}$ & $2.93 \times 10^{-8}$ & $5.77 \times 10^{-8}$ & $9.79 \times 10^{-8}$ & $1.64 \times 10^{-5}$ & $55.1 \pm 0.1$ \\
\hline $\mathrm{Sn}-\mathrm{Zn} 0.5 \mathrm{Ga}$ & $4.31 \times 10^{-8}$ & $8.11 \times 10^{-8}$ & $1.37 \times 10^{-7}$ & $1.42 \times 10^{-4}$ & $52.9 \pm 0.1$ \\
\hline
\end{tabular}

formation of the $\mathrm{Ni}_{5} \mathrm{Zn}_{21}$ layer, growth is controlled by the diffusion process. The same character of changes was observed in Refs. 12, 18, and 30. The phases occurring during soldering with $\mathrm{Sn}-\mathrm{Zn}$ on $\mathrm{Ni}$ substrate show that for lower Zn content (up to 3 (wt.\%)), ${ }^{17}(\mathrm{Zn}, \mathrm{Ni})_{3} \mathrm{Sn}_{4}$ formed at the interface. With increasing time, particles of the $\mathrm{Ni}_{5} \mathrm{Zn}_{21}$ phase were observed at the front of the interface. The stability of the formed phases is shown in Ref. 18 for Sn9.0Zn with 1.0 (wt.\%) $\mathrm{Cu}$ at a temperature of $528\left(255^{\circ} \mathrm{C}\right)$ on $\mathrm{Ni}$ substrate. After $3 \mathrm{~h}$, only the $\mathrm{Cu}_{5} \mathrm{Zn}_{8}$ layer was observed at the interface, but with increasing time the diffusion of $\mathrm{Ni}$ to the interface caused the formation of a $\mathrm{Ni}_{5} \mathrm{Zn}_{21}$ layer and degradation of the $\mathrm{Cu}_{5} \mathrm{Zn}_{8}$ layer. Over a very long time, the system strives to obtain equilibrium, and other binary or ternary phases $\left(\tau_{1}\right.$ and $\tau_{2}$ ) from the Ni-Sn-Zn system will be formed at the local area, as shown in phase diagram. ${ }^{14,47}$ The studies ${ }^{15-18}$ show that lower Zn content, or reduced $\mathrm{Zn}$ concentration via alloying additions, caused a phase with Sn to occur at the interface, as a result of the diffusion of $\mathrm{Ni}$ to the solder during the experiment.

\section{CONCLUSIONS}

The spreading behavior of Sn-Zn0.2Na and Sn$\mathrm{Zn} 0.5 \mathrm{Ga}$ alloys on $\mathrm{Al}$ and $\mathrm{Ni}$ substrates was studied using the SD method in the presence of AlU $33^{\circledR}$ flux. It was found that the examined alloys exhibited good, or at least sufficient, wetting on both types of substrate. However, a different character of spreading area on the $\mathrm{Al}$ substrate was obtained for $\mathrm{Sn}$ $\mathrm{Zn} 0.2 \mathrm{Na}$ and Sn-Zn0.5Ga alloys. For the Sn$\mathrm{Zn} 0.5 \mathrm{Ga}$ alloy, the spreading area reduced with temperature and time, compared to the $\mathrm{Sn}-\mathrm{Zn} 0.2 \mathrm{Na}$ alloy [where, at $523 \mathrm{~K}$ and $553 \mathrm{~K}\left(250^{\circ} \mathrm{C}\right.$ and $280^{\circ} \mathrm{C}$ ), the spreading area increased over time]. Different microstructures were obtained for $\mathrm{Al}$ and $\mathrm{Ni}$ substrates, resulting from different chemical reactions of the liquid alloys with the substrates. The $\mathrm{Al}$ substrates dissolved in liquid solder. On the other hand, an IMC layer formed at the interface on the $\mathrm{Ni}$ substrate. For the $\mathrm{Al}$ substrate, the $\mathrm{Al}$ dissolved in the liquid solder and diffused to the drop for both the Sn-Zn0.2Na and the Sn-Zn0.5Ga alloys. With increasing temperature, grain boundary dissolution of the Al substrate occurred, causing the detachment of whole grains. In the case of soldered Ni couples, a $\mathrm{Ni}_{5} \mathrm{Zn}_{21}$ IMC was formed at the interface. Similar thicknesses were obtained for both the $\mathrm{Sn}-\mathrm{Zn} 0.2 \mathrm{Na}$ and the $\mathrm{Sn}-\mathrm{Zn} 0.5 \mathrm{Ga}$ alloys. The growth rate is controlled by the grain boundary process, and the corresponding chemical reaction constants, kinetic parameters and their corresponding activation energies were also determined in this work. A slightly higher effect resulting from the addition of Na to eutectic Sn-Zn alloy (compared to the $\mathrm{Ga}$ addition) on the growth rate of $\mathrm{Ni}_{5} \mathrm{Zn}_{21}$ was observed. The $\mathrm{Na}$ content by formation of $\mathrm{NaZn}_{13}$ precipitates has a greater influence on the growth of $\mathrm{Ni}_{5} \mathrm{Zn}_{21}$ compared to dissolved $\mathrm{Ga}$. In the case of $\mathrm{Al}$ substrate, the substrate was observed to dissolve for both $\mathrm{Na}$ and $\mathrm{Ga}$ content. However, different $\mathrm{Zn}$ morphologies at the interface are observed for additions of $\mathrm{Ga}$ and $\mathrm{Na}$ to eutectic SnZn alloy. For $\mathrm{Ga}$ content, the $\mathrm{Zn}$ particles are globular, while for $\mathrm{Na}$ content, the $\mathrm{Zn}$ occurs in the form of needles.

\section{ACKNOWLEDGEMENT}

This work was financed by the National Science Centre Poland grant 2013/09/D/ST8/03991 "Physicochemical properties of $\mathrm{Sn}-\mathrm{Zn}+\mathrm{X}(\mathrm{X}=\mathrm{Ga}, \mathrm{Na})$ alloys" in the years $2014-2017$.

\section{OPEN ACCESS}

This article is distributed under the terms of the Creative Commons Attribution 4.0 International License (http://creativecommons.org/licenses/by/4.0/), which permits unrestricted use, distribution, and reproduction in any medium, provided you give appropriate credit to the original author(s) and the source, provide a link to the Creative Commons license, and indicate if changes were made.

\section{REFERENCES}

1. L. Zhang and K.N. Tu, Mater. Sci. Eng. R 82, 1 (2014).

2. K.S. Kim, J.M. Yang, C.H. Yu, I.O. Jung, and H.H. Kim, J. Alloys Compd. 379, 314 (2004).

3. T. Gancarz, Mater. Trans. A 47, 326 (2016).

4. T. Gancarz, J. Pstrus, W. Gasior, and H. Henein, J. Electron. Mater. 42, 288 (2013).

5. A.K. Gain and L. Zhang, J. Alloys Compd. 617, 779 (2014).

6. C.-Y. Liu, M.-H. Hon, M.-C. Wang, Y.-R. Chen, K.-M. Chang, and W.-L. Li, J. Alloys Compd. 582, 229 (2014).

7. L.L. Duan, D.Q. Yu, S.Q. Han, H.T. Ma, and L. Wang, J. Alloys Compd. 381, 202 (2004).

8. J. Pstruś, P. Fima, and T. Gancarz, J. Mater. Eng. Perform. 21, 606 (2012).

9. K.S. Kim, S.H. Huh, and K. Suganuma, J. Alloys Compd. 352, 226 (2003).

10. M. Date, T. Shoji, M. Fujiyoshi, K. Sato, and K.N. Tu, Scripta Metall. 51, 641 (2004). 
11. C.-W. Huang and K.-L. Lin, Mater. Trans. A 45, 588 (2004).

12. D. Soares, C. Vilarinho, J. Barbosa, F. Samuel, L. Trigo, and P. Bre, J. Min. Metall. Sect. B 43, 131 (2007).

13. A. Sharif and Y.C. Chan, J. Alloys Compd. 440, 117 (2007).

14. V.D. Gandova, P. Broz, and J. Buršík, Thermochim. Acta 524,47 (2011)

15. C.-H. Wang, H.-H. Chen, P.-Y. Li, and P.-Y. Chu, Intermetallics 22, 166 (2012).

16. Y.-C. Chan, M.-Y. Chiu, and T.-H. Chuang, Z. Metallkd. 93, 95 (2002).

17. C.-H. Wang and H.-H. Chen, J. Electron. Mater. 39, 2375 (2010).

18. W.-K. Liou, Y.-W. Yen, and C.-C. Jao, J. Electron. Mater. 38, 2222 (2009).

19. Y.-W. Yen, D.-W. Liaw, K.-D. Chen, and H. Chen, J. Electron. Mater. 39, 2412 (2010).

20. W. Zhu, H. Liu, J. Wang, G. Ma, and Z. Jin, J. Electron. Mater. 39, 209 (2010).

21. T. Gancarz and P. Fima, J. Mater. Eng. Perform. 25, 3358 (2016). doi:10.1007/s11665-016-2029-0.

22. T. Gancarz, P. Bobrowski, J. Pstrus, and S. Pawlak, J. Alloys Compd. 679, 442 (2016). doi:10.1016/j.jallcom.2016. 04.040.

23. M.L. Huang, Y.Z. Huang, H.T. Ma, and J. Zhao, J. Electron. Mater. 40, 315 (2011).

24. Y. Li, X. Leng, S. Cheng, and J. Yan, Mater. Des. 40, 427 (2012).

25. L.M. Satizabal, D. Costa, G.O. Hainick, D.R. Moura, A.D. Bortolozo, and W.R. Osório, Metall. Mater. Trans. 48A, 1880 (2017)

26. Z. Lai, Z. Lai, and D. Ye, J. Mater. Sci.: Mater. Electron. 27, $3182(2016)$

27. Z. Lai and D. Ye, J. Mater. Sci.: Mater. Electron. 27, 1 (2016).

28. W.R. Osório, L.R. Garcia, L.C. Peixoto, and A. Garcia, Mater. Des. 32, 4763 (2011).

29. W.R. Osório and A. Garcia, Sci. Technol. Weld. Join. 21, 429 (2016).
30. P. Fima, K. Berent, J. Pstruś, and T. Gancarz, J. Mater. Sci. 24, 8472 (2012).

31. L. Zhang, S.-b. Xue, L.-l. Gao, Z. Sheng, H. Ye, Z.-x. Xiao, G. Zeng, Y. Chen, and S.-l. Yu, J. Mater. Sci.: Mater. Electron. 21, 1 (2010).

32. T. Gancarz and W. Gasior, Fluid Phase Equilib. 418, 57 (2016). doi:10.1016/j.fluid.2015.09.009.

33. B. Klöden, Ph.D.-Thesis Institut für Strukturphysik, TU Dresden, 2006.

34. M. Trybula, T. Gancarz, W. Gasior, and A. Pasturel, Metall. Mater. Trans. A 45, 5517 (2014).

35. K.C. Mills and Y.C. Su, Int. Mater. Rev. 51, 329 (2006).

36. B. Smetana, S. Zla, A. Kroupa, M. Zaludova, J. Drapala, R. Burkovic, and D. Petlak, J. Therm. Anal. Calorim. 110, 369 (2012).

37. L.R. Garcia, L.C. Peixoto, W.R. Osorio, and A. Garcia, Mater. Lett. 63, 1314 (2009).

38. Y.S. Kim, K.S. Kim, C.W. Hwang, and K. Suganuma, J. Alloys Compd. 352, 233 (2003).

39. C. Wei, Y.C. Liu, Y.J. Han, J.B. Wan, and K. Yang, J. Alloys Compd. 464, 301 (2008).

40. W.X. Yuan, Z.Y. Qiao, H. Ipser, and G. Eriksson, J. Phase Equilib. Differ. 25, 68 (2004).

41. A. Johansson, H. Ljung, and S. Westman, Acta Chem. Scand. 22, 2743 (1968).

42. W. Jeitschko and B. Jaberg, Acta Crystallogr. B 38, 598 (1982).

43. G.F. Zhou, L.M. Di, and H. Bakker, J. Appl. Phys. 73, 1521 (1993).

44. P. Shoemaker, R.E. Marsh, F.J. Ewing, and L. Pauling, Acta Crystallogr. 5, 637 (1952).

45. M. Schaefer, R.A. Fournelle, and J. Liang, J. Electron. Mater. 27, 1167 (1998).

46. Y.-W. Yen, C.-C. Jao, K.-S. Chao, and S.-M. Fu, Proceedings of the World Congress on Engineering 2011 Vol. II WCE 2011, July 6-8, 2011, London, UK. ISSN: 2078-0966.

47. J. Chang, S.-K. Seo, and H.M. Lee, J. Electron. Mater. 39, 2643 (2010). 